\title{
Pengembangan Desa Lok Baintan dengan Pemanfaatan Sampah Ilung menjadi Kertas
}

\section{The Development of Lok Baintan Village by Utilizing Ilung Waste into Paper}

\author{
Muzahid Akbar Hayat", Sanusi
}

Prodi Magister Ilmu Komunikasi, Universitas Islam Kalimantan Muhammad Arsyad Al Banjari, Jl. Adhyaksa No. 2 Kayutangi, Banjarmasin, Kalimantan Selatan, Indonesia

\begin{tabular}{|c|c|}
\hline Info Artikel & ABSTRAK \\
\hline $\begin{array}{l}\text { Diterima } 28 \text { Juni } 2019 \\
\text { Ditelaah 1 Agustus } 2019 \\
\text { Disetujui 26 September } 2019 \\
\text { Tersedia daring } 30 \text { Oktober } \\
2019 \\
\text { *Penulis untuk korespondensi } \\
\text { m.akbarhayat@ gmail.com }\end{array}$ & $\begin{array}{l}\text { Lok Baintan adalah desa tertinggal yang merupakan ikon wisata di Banjarmasin, } \\
\text { Kalimantan Selatan, melalui pasar terapungnya. Penggunaan Kelotok (perahu } \\
\text { tradisional) adalah primadona wisatawan lokal dan asing. Namun, perjalanan itu } \\
\text { terganggu mengingat jumlah eceng gondok yang begitu banyak di sepanjang sungai } \\
\text { Martapura. Masyarakat setempat mengenal eceng gondok dengan sebutan "ilung". Ilung } \\
\text { adalah tanaman gulma yang tumbuh sangat cepat. Tujuan pengabdian pada masyarakat } \\
\text { ini adalah untuk mengatasi maraknya ilung melalui pelatihan masyarakat di Desa Lok } \\
\text { Baintan untuk menghasilkan produk yang layak dijual yakni menjadi kertas. Metode } \\
\text { yang digunakan dalam program ini adalah komunikasi partisipatif. Semua pihak } \\
\text { diundang untuk berpartisipasi dalam proses komunikasi untuk pengambilan keputusan } \\
\text { melalui dialog, pendampingan, dan pemberdayaan yang dirancang bersama dan } \\
\text { berkelanjutan. Hasilnya, masyarakat memiliki peningkatan pengetahuan dan } \\
\text { keterampilan baru. Produk dari kegiatan pengabdian pada masyarakat ini adalah kertas, } \\
\text { amplop dan tas kertas. }\end{array}$ \\
\hline $\begin{array}{l}\text { Keywords: } \\
\text { Disadvantaged village } \\
\text { Participatory communication } \\
\text { Water hyacinth }\end{array}$ & $\begin{array}{l}\text { ABSTRACT } \\
\text { Lok Baintan Village is a tourism icon of Banjarmasin, South Kalimantan, through the } \\
\text { floating market, but it is classified as a disadvantaged village. The use of Kelotok } \\
\text { (traditional boat) is the favorite choice of both local and foreign tourists. However, the } \\
\text { trip is disturbed considering the amount of water hyacinth, local people call it as "ilung", } \\
\text { waste around the Martapura River. Ilung is a weed plant that grows very fast. The aim } \\
\text { of this community service was to overcome the problem by training the community in } \\
\text { Lok Baintan to produce a selling product, such as paper, from water hyacinth. The } \\
\text { method used in this program was participatory communication. All parties were invited } \\
\text { to participate in the communication process to decision making through dialogue, } \\
\text { mentoring, and empowerment that were designed together and were sustainable. As a } \\
\text { result, the Lok Baintan people had an improved-knowledge and a new skill. The products } \\
\text { of this community service were paper, envelope and paper bag. }\end{array}$ \\
\hline
\end{tabular}

ISSN 2685-0354 (Media Online). Diterbitkan oleh Universitas Prof. Dr. Hazairin, SH. Ini merupakan jurnal bebas akses di bawah lisensi Creative Commons Atribution 4.0 International (https://creativecommons.org/licenses/by/4.0

\section{PENDAHULUAN}

Banjarmasin merupakan kota yang dijuluki sebagai kota "seribu sungai” yang didominasi oleh dataran rendah. Sebagian dari hamparan dataran rendah tersebut, terutama di wilayah bagian barat, merupakan dataran rawa. Vegetasi yang dominan pada wilayah ini adalah hutan rawa, hutan bakau dan jenis-jenis rumput rawa. Sungai-sungai besar berfungsi sebagai sarana transportasi yang penting bagi kehidupan ekonomi dan sosial masyarakat Kalimantan Selatan. Sungai Barito yang panjangnya sekitar 900 kilometer merupakan sungai terbesar yang mempunyai beberapa anak sungai. 
Desa Lok Baintan merupakan salah satu desa yang berada di Kecamatan Sungai Tabuk, Kabupaten Banjar, Provinsi Kalimantan Selatan, yang aksesnya lebih banyak menggunakan sungai. Desa tersebut termasuk salah satu desa tertinggal di Kalimantan Selatan berdasarkan Keputusan Menteri Desa, Pembangunan Daerah Tertinggal dan Transmigrasi Republik Indonesia, nomor 126 tahun 2017, data No.12067, (ID: 6303040010). Namun, desa tersebut merupakan salah satu tujuan wisata yang terkenal dengan pasar terapung. Jalan menuju tempat wisata dilalui dengan darat tetapi tidak memadai, dan kebanyakan dilalui dengan menggunakan transportasi sungai yaitu kapal kecil, yang disebut dengan Kelotok. Transportasi sungai ini merupakan jalur yang paling disukai para wisatawan lokal dan manca negara. Namun, kelotok atau alat transportasi perahu lebih lama sampai ke tujuan karena berjalan dengan menghindari tumbuhan yang memenuhi sungai yaitu eceng gondok.

Tumbuhan eceng gondok (Eichhornia crassipes) dalam bahasa Banjar di sebut "ilung" dan selanjutnya eceng gondok akan dituliskan sebagai ilung di dalam artikel ini. Ilung adalah tumbuhan air yang tumbuh dirawa-rawa sungai dan danau. Pertumbuhan ilung sangat cepat dan mampu menutupi seluruh permukaan sungai. Ilung dapat berkembang biak dengan dua cara yaitu dengan tunas dan biji. Ilung termasuk dalam kelompok gulma perairan yang memiliki kemampuan berkembangbiak secara cepat terutama di daerah tropis dan subtropis.

Kehadiran ilung sangat mencemaskan sehingga menjadi katagori sampah sungai. Sampah ilung yang ada di sungai pernah hampir menutupi aliran sungai sehingga menyulitkan warga dan wisatawan menggunakan jalur transportasi sungai tersebut. Salah satu dampak yang signifikan adalah waktu tempuh yang lebih lama sehingga banyak wisatawan yang tertinggal menyaksikan transaksi pasar terapung. Kondisi merugikan lain dari sampah ilung menurut Taufikurahman (2008), antara lain: (1) meningkatnya evapontranspirasi, (2) menurunnya jumlah cahaya yang masuk ke dalam perairan sehingga menyebabkan menurunnya tingkat kelarutan oksigen dalam air (DO: Dissolved Oxygen), (3) mengganggu lalu lintas (transportasi) air, khususnya bagi masyarakat yang kehidupannya masih tergantung dari sungai seperti di pedalaman Kalimantan dan beberapa daerah lainnya. (4) meningkatnya habitat bagi vektor penyakit pada manusia, dan (5) menurunkan nilai estetika lingkungan perairan.

Salah satu upaya yang bisa dilakukan untuk mengurangi ilung adalah dengan memanfaatkan ilung menjadi produk bernilai jual melalui kegiatan ekonomi kreatif. Masyarakat ekonomi kreatif adalah usaha yang dilakukan oleh masyarakat setempat untuk peningkatan penghasilan jati dirinya. Dalam kegiatan ini, masyarakat menggunakan ilung sebagai bahan utama pembuatan kertas dan menjadikan produk wirausaha ekonomi kreatif. Menurut Lim (2008), masyarakat ekonomi kreatif merupakan pola pengembangan kewirausahaan yang menopang kegiatan usaha dengan pemanfaatan potensi alam.

Membangun masyarakat kreatif memerlukan komunikasi sebagai pendukung dan komunikasi horizontal dapat diterapkan sebagai modelnya yaitu interaksi komunikasi yang dilakukan secara lebih demokratis. Kegiatan komunikasi bukan kegiatan memberi dan menerima melainkan berbagi dan berdialog (Pranarka \& Moeljarto sebagaimana dikutip dari Priyono \& Pranarka, 1996). Selama ini, keterlibatan masyarakat hanya dilihat dalam konteks yang sempit, artinya manusia cukup dipandang sebagai tenaga kasar untuk mengurangi biaya pembangunan sosial. Dengan kondisi ini, peran serta masyarakat terbatas pada implementasi atau penerapan program dimana daya masyarakat tidak dikembangkan menjadi kreatif dari dalam dirinya dan harus menerima keputusan yang sudah diambil pihak luar. Kehadiran komunikasi adalah untuk melakukan proses penyadaran pada masyarakat terhadap situasi kondisi lingkungan dengan melihat kondisi dan kemampuan dari masyarakat tersebut. Proses penyadaran membutuhkan banyak dialog yang merupakan proses komunikasi dua arah berkelanjutan sampai pada tahap menemukan suatu pemahaman dan pengertian hingga membentuk suatu kesadaran. Salah satu pendekatan komunikasi dalam rangka meningkatkan kesadaran adalah komunikasi partisipatif. Komunikasi partisipatif dapat memotivasi masyarakat untuk berpartisipasi dalam pembuatan keputusan dalam mencapai sesuatu. Sejalan dengan itu, Rinawati (2006) menjelaskan peranan komunikasi dalam memotivasi masyarakat menumbuhkan kebutuhan mencapai sesuatu berperan begitu penting.

Komunikasi partisipatif adalah suatu proses komunikasi dimana terjadi komunikasi dua arah atau dialogis, sehingga menghasilkan suatu pemahaman yang sama terhadap pesan yang disampaikan (Rahim, 1994). Kegiatan komunikasi partisipatif adalah kegiatan yang bukan hanya memberi dan menerima namun lebih kepada berbagi dan berdialog. Komunikasi pembangunan berarti berbagi pengetahuan yang mengarah pada pencapaian suatu konsensus untuk tindakan yang mempertimbangkan minat, kebutuhan-kebutuhan dan kapasitas dari semua yang terkait. Komunikasi telah menjadi bagian strategis yang perlu dicantumkan dalam setiap perencanaan pembangunan yang bersifat partisipatif (Servaes, 2005).

Situasi di sekitar Sungai Martapura, Desa Lok Baintan perlu diselesaikaan secara sistemik dan berkelanjutan. Sampah sungai berupa tumbuhan ilung harus diatasi dengan keterlibatan masyarakat. Solusi yang ditawarkan dalam 
menyelesaikan sampah ilung di sungai adalah melalui pemberdayaan masyarakat dengan pendekatan komunikasi partisipatif.

Program Pengembangan Desa Mitra dari Kementerian Riset, Teknologi dan Pendidikan Tinggi melalui Pemberdayaan Masyarakat Peduli Lingkungan "Desa Sahabat Sampah" dirancang untuk menyelesaikan permasalahan sampah ilung di sungai dengan mengedepankan konsep ekonomi kreatif keberlanjutan. Kegiatan pemanfaatan ilung menjadi kertas merupakan salah satu solusi dalam mengatasi maraknya sampah ilung di sungai. Upaya ini dilakukan dalam rangka mengurangi sampah ilung di sungai. Ilung menjadi bahan baku utama dalam pembuatan kertas, kartu nama, dan amplop. Tujuan dari kegiatan pengabdian ini adalah: (1) membersihkan sungai dari sampah ilung agar tidak mengganggu transportasi sungai, dan (2) memanfaakan ilung menjadi produk yang bermanfaat dan bernilai jual dengan memberdayakan masyarakat ekonomi kreatif.

\section{METODE}

Kegiatan ini dilakukan di Kantor Desa Lok Baintan Kecamatan Sungai Tabuk, Kabupaten Banjar, Provinsi Kalimantan Selatan. Survei awal ke lokasi, diskusi, pelaksanaan kegiatan hingga pengambilan/pengumpulan data dilaksanakan sejak bulan September 2018 hingga Juli 2019 (Tabel 1).

Tabel 1. Pengambilan dan Pengumpulan Data

\begin{tabular}{llll}
\hline No & Nama kegiatan & Tanggal & Peserta \\
\hline 1. & FGD & 10 April 2019 & $\begin{array}{l}\text { Tokoh masyarakat, Kepala desa, Ketua } \\
\text { PKK dan Ketua Karang Taruna }\end{array}$ \\
\hline 2. & Pendidikan dan Pelatihan & $\begin{array}{l}11 \text { April 2019 sd. 16 } \\
\text { April 2019 }\end{array}$ & $\begin{array}{l}\text { Kepala desa, Ketua PKK dan Ketua } \\
\text { Karang Taruna }\end{array}$ \\
\hline 3. & Pendidikan dan Pelatihan & 04 Juli 2019 sd. 07 Juli & $\begin{array}{l}\text { Kepala desa, Ketua PKK dan Ketua } \\
\text { Karang Taruna }\end{array}$ \\
\hline
\end{tabular}

Subjek dari kegiatan ini adalah para anggota Karang Taruna dan anggota Pemberdayaan Kesejahteraan Keluarga (PKK) Desa Lok Baintan. Dukungan juga diberikan oleh lembaga pemerintahan yaitu Kepala Desa atau disebut Pembakal dan tokoh masyarakat setempat. Jumlah subjek dari kegiatan ini ada 17 orang.

Data diperoleh dengan menggunakan teknik pengumpulan data melalui studi dokumentasi dan pengamatan langsung. Kegiatan pengembangan Desa Lok Baintan dilakukan dengan metode pendekatan partisipatif yaitu dengan melakukan beberapa hal:

1. Dialog publik

Dialog publik merupakan bagian dari komunikasi publik yaitu komunikasi antara sesorang pembicara dengan sejumlah besar orang (khalayak) yang tidak bisa dikenal satu persatu (Mulyana, 2007). Dialog publik dilakukan untuk mengawali kegiatan pengabdian. Peserta yang diundang dalam dialog publik ini adalah perwakilan masyarakat Desa Lok Baintan dan Kepala Desa, Karang Taruna dan PKK untuk ditawarkan solusi dalam mengatasi permasalahan limbah ilung.

2. Focus Group Discussion (FGD)

FGD merupakan metode komunikasi dengan melakukan diskusi kelompok terarah guna mengumpulkan data kualitatif dan memperoleh pengertian yang lebih seksama. FGD memiliki kelebihan yaitu dapat mengembangkan kreativitas dan dapat mengemukakan pendapat yang berbeda sehingga dapat memunculkan analisis data para persertanya (Machfoedz \& Suryani, 2008). Kegiatan FGD dilakukan untuk mengetahui permasalahan ilung lebih dalam, langkah masyarakat, peran masyarakat dan pernyamaan persepsi tentang program Pengembangan Desa Mitra. 3. Pelatihan kontinum relationship.

Menurut Aronson, Bostic, Huck, dan Rownsen (2014), ada tiga komponen yang harus dilalui dalam pelatihan kontinum relationship. Ketiga komponen itu adalah masukan (input), proses dan keluaran (output) (Gambar 1). Pelatihan kontinum relationship dilaksanakan dengan mengumpulkan pemuda karang taruna dan Ibu PKK. Tahap awal pelatihan kontinum relationship adalah sosialisasi program. Sosialisasi diberikan kepada karang taruna dan anggota PKK. Selanjutnya, peserta diberikan materi tentang daur ulang ilung melalui kegiatan pelatihan. Pelatih yang dipilih adalah narasumber yang telah memiliki pengalaman dan pakar dibidang pengolahan sampah/limbah untuk memberikan pelatihan daur ulang ilung dan diakhiri dengan hasil produk nyata yaitu ilung menjadi kertas. Budiman, 
Mawardi, dan Hakim (2017) menyatakan bahwa produk merupakan sesuatu yang ditawakan kepada pasar, baik barang yang berwujud maupun yang berupa jasa. Produk digunakan untuk memenuhi kebutuhan dan memuaskan keinginan.

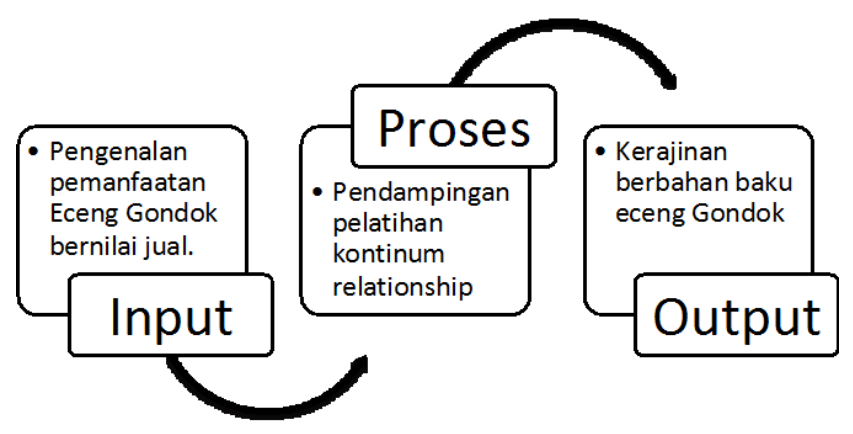

Gambar 1 Model pelatihan kontinum relationship

\section{HASIL DAN PEMBAHASAN}

Kegiatan pengabdian dimulai dengan melakukan dialog publik melalui FGD dengan Kepala Desa, Ketua PKK dan Ketua Karang Taruna. Berdasarkan pengamatan langsung di lokasi dan diskusi tim dengan mitra, permasalahan yang ada terkait dengan keberadaan sampah ilung adalah rendahnya pengetahuan masyarakat dan kurangnya keterampilan masyarakat dalam mengolah sampah ilung menjadi produk yang bernilai jual. Oleh karena itu, solusi yang ditawarkan dengan program pemberdayaan masyarakat adalah memanfaatkan ilung menjadi kertas. Dialog tersebut juga ditujukan untuk menentukan peserta peningkatan kemampuan dalam mengolah limbah ilung. Penentuan sumber daya manusia merupakan kunci utama dalam program ini. Seleksi awal sangat penting sehingga diharapkan dapat menghasilkan sumber daya manusia yang berkualitas dan mampu menjadi sumber informasi baru atau instruktur baru dalam progam tersebut. Syarat untuk bisa menjadi peserta adalah memiliki waktu untuk setiap kegiatan, tidak memiliki anak berusia dibawah 3 tahun, bisa membaca, tidak buta warna, memiliki minat belajar dan bertanggung jawab. Panitia mengundang 75\% dari jumlah penduduk di Desa Lok Baintan yang berjumlah 1.507 yaitu 1.130 orang. Dari undangan yang tersebar, hanya 40 orang yang bisa hadir untuk penseleksian. Hasilnya adalah 17 orang dapat mengikuti program ini (Tabel 2).

Tabel 2. Identifikasi permasalahan dan justifikasi

\begin{tabular}{|c|c|c|c|}
\hline No. & Permasalahan & Justifikasi & Anggota Yang Terlibat \\
\hline 1. & $\begin{array}{l}\text { Rendahnya pengetahuan masyarakat } \\
\text { tentang pemanfaatan sampah ilung }\end{array}$ & $\begin{array}{l}\text { Sosialisasi tentang pengelolahan } \\
\text { sampah ilung untuk kerajinan; } \\
\text { Sosialisasi alat-alat yang digunakan } \\
\text { dalam proses pengelolahan ilung; } \\
\text { Pemetaan pemecahan masalah; } \\
\text { Membuat rencana implementasi. }\end{array}$ & $\begin{array}{l}\text { Kepala Desa dan } 17 \\
\text { orang dari PKK dan } \\
\text { Karang Taruna }\end{array}$ \\
\hline 2. & Tidak mengetahui pengolahan ilung & $\begin{array}{l}\text { Pelatihan pemanfaatan ilung dari daun } \\
\text { hingga akar; } \\
\text { Membuat rumusan olahan dari ilung; } \\
\text { Membuat kertas dari ilung. }\end{array}$ & $\begin{array}{l}\text { Kepala Desa dan } 17 \\
\text { orang dari PKK dan } \\
\text { Karang Taruna }\end{array}$ \\
\hline 3. & $\begin{array}{l}\text { Tidak mengetahui produk yang } \\
\text { bernilai jual }\end{array}$ & $\begin{array}{l}\text { Pelatihan pembuatan kertas dari ilung; } \\
\text { Pelatihan membuat amplop dan kantong } \\
\text { kertas dari ilung. }\end{array}$ & $\begin{array}{l}\text { Kepala Desa dan } 17 \\
\text { orang dari PKK dan } \\
\text { Karang Taruna }\end{array}$ \\
\hline
\end{tabular}

Kegiatan pemanfaatan limbah ilung berbasis keberlanjutan dilakukan oleh masyarakat sekitaran sungai di Desa Lok Baintan dengan kreatifitas sebagai fundamentalnya. Mengubah ilung menjadi kertas merupakan salah satu solusi mengurangi sampah ilung. Pengurangan sampah ilung ini dilakukan dalam rangka meningkatkan wisatawan asing dan 
lokal dan meningkatkan perekonomian warga setempat. Kegiatan dilakukan di bulan April 2019 dan di bulan Juli 2019 di Desa Lok Baintan dengan rincian sebagai berikut:

1. Masukan (Input)

Ini merupakan proses pengenalan atau identifikasi dan sosialisasi program yang akan dilaksanakan di Desa Lok Baintan Kalimantan Selatan terhadap angota PKK dan Karang Taruna.

a. Sosialisasi Program

Sosialisasi dilakukan melalui dialog dengan Kepala Desa dan peserta dalam kategori pelatihan sesuai dengan kebutuhan dan keadaan peserta. Peserta secara Bersama-sama menentukan kebutuhan akan teknologi tepat guna yang mampu memberikan solusi yang sesuai dari hulu hingga ke hilir. Program dilaksanakan dengan pelatihan, pendampingan dan pemberdayaan hingga mampu menghasilkan nilai yang dapat meningkatkan perekonomian masyarakat setempat.

b. Metode Pelatihan

Pelatihan pemanfaatan ilung menjadi produk bernilai jual ini dilakukan dengan 3 metode, yaitu:

1. Dialog tukar pikiran dan sumbang saran yaitu proses dalam menentukan tempat, jadwal dan produk yang dibuat dan disepakati bersama;

2. Ceramah dengan menggundang pakar daur ulang sehingga menjadi inspirasi dan wawasan dalam berkreasi;

3. Kaderisasi yaitu menciptakan sumber daya manusia berjiwa pengusaha yang memiliki kompetensi, kemampuan produksi dan mampu berdaya saing.

2. Proses Pendampingan

a. Tahap Pengenalan

1. Pengenalan alat-alat yang digunakan seperti pencacah, penghalus, pembentuk bubur kertas, pengering dan pencetak;

2. Pengenalan bagian ilung yang digunakan dan hasil dari masing-masing bagian;

3. Pengenalan bahan-bahan yang digunakan

b. Tahap Pembuatan

1. Ilung dibersihkan dari kotoran yang menempel;

2. Ilung yang bersih dipotong-potong (dicacah) sebagian, sebagian lainnya dijemur dan sebagian lagi langsung dihaluskan (Gambar 2);

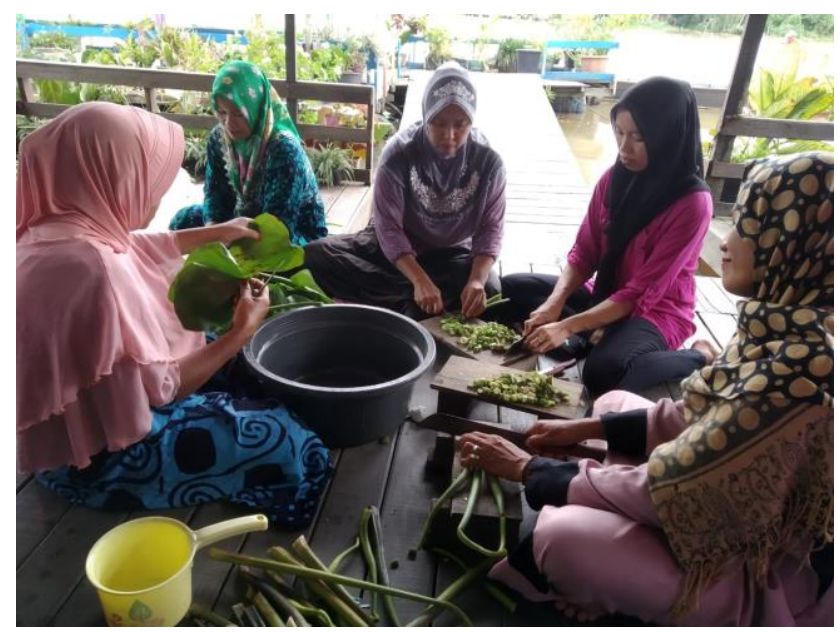

Gambar 2 Kegiatan Masyarakat melakukan pencacahan ilung di Lok Baintan

3. Ilung kering ataupun basah di haluskan menjadi bubur;

4. Bubur ilung di cetak dalam dua ukuran A4 dan A3 (Gambar 3); 


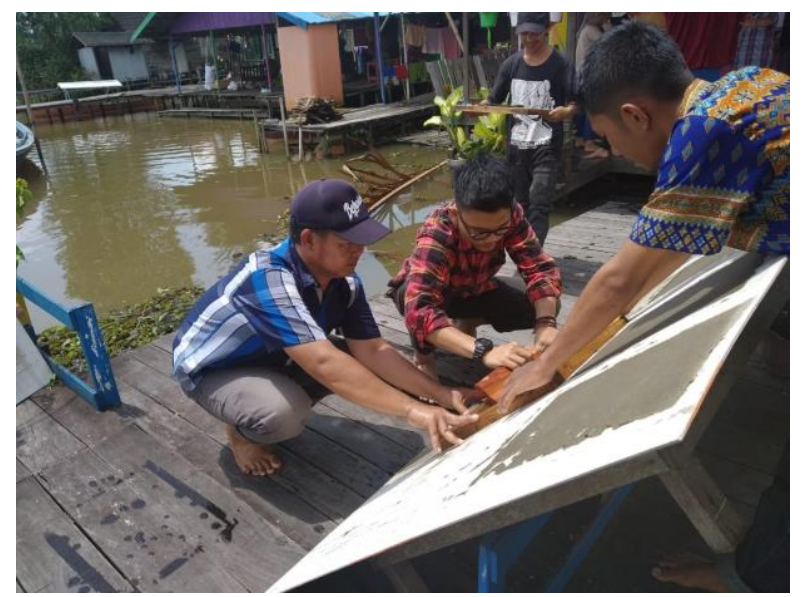

Gambar 3 Kegiatan Masyarakat melakukan pencetakan bubur kertas dari ilung di Lok Baintan

5. Cetakan dijemur selama 4 sampai 6 jam tergantung panas matahari (Gambar 4).

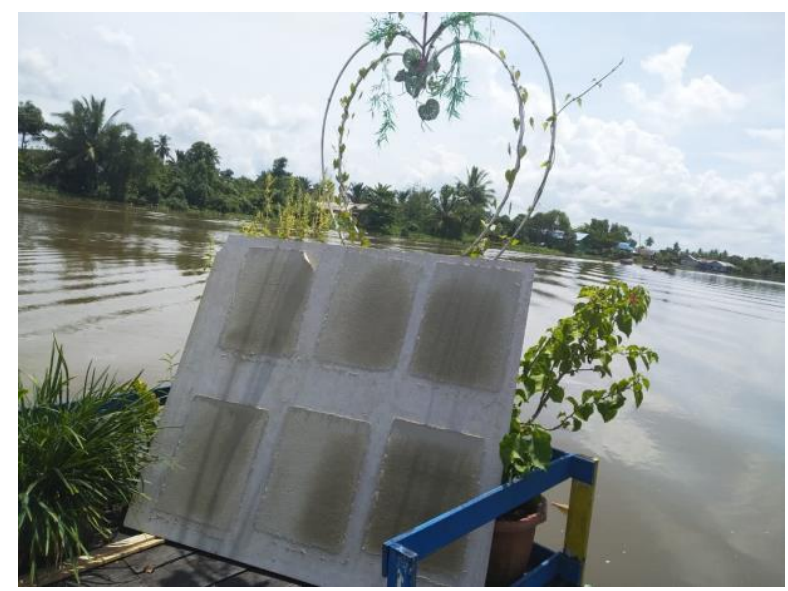

Gambar 4 Proses penjemuran kertas dari ilung di Lok Baintan

\section{Keluaran (Output)}

Produk pengolahan sampah ilung dalam kegiatan ini adalah kertas ukuran A4 dan A3 dengan hasil kreatifitasnya seperti amplop, paper bag, dan kartu nama (Gambar 5). Produk ini diharapkan mampu meningkatkan ekonomi kreatif masyarakat desa Lok Baintan Kalimantan Selatan.

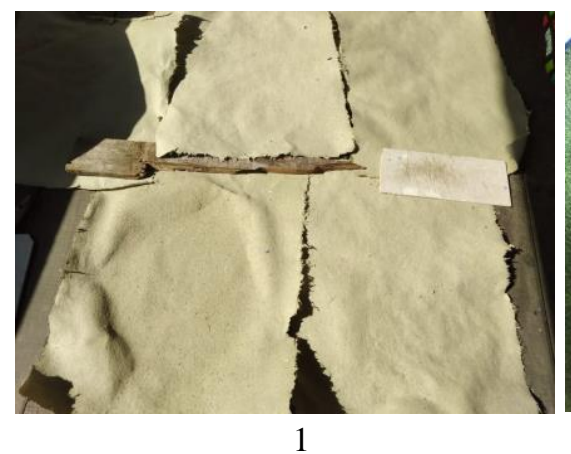

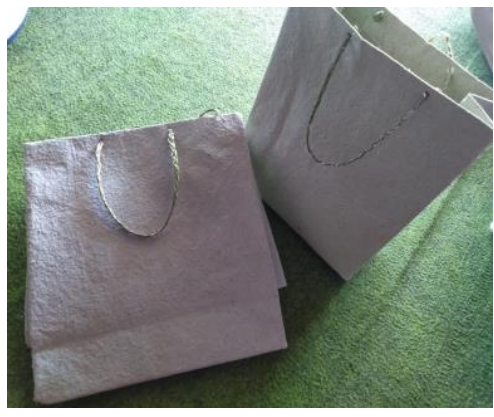

2

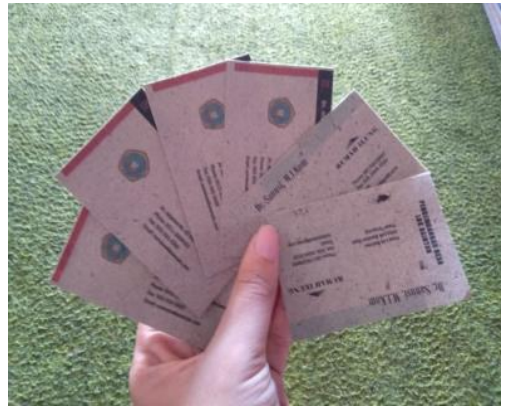

3

Gambar 5 Hasil dari olahan ilung menjadi 1) kertas; 2) kantong kertas; dan 3) kartu nama

Masyarakat mampu memproduksi 100 sampai dengan 150 kertas ilung dalam satu hari tergantung proses penjemuran dan cuaca dihari tersebut. Biaya produksi untuk satu lembar kertas adalah Rp. 200,-. Masyarakat menjual kertas dengan harga Rp.500,- per lembar. Kertas yang dijadikan produk turunan memiliki nilai jual lebih tinggi. Harga amplop adalah Rp.1.000, - per satuan. Harga kartu nama adalah Rp. 50.000,- per kotak. Harga kantong/tas kertas 
adalah Rp.3.000,- per satuan. Program dilakukan dengan melibatkan masyarakat dengan proses komunikasi partisipatif dari awal hingga tahap pembuatan keputusan. Proses ini menghasilkan peningkatkan soft skill) dan hard skill masyarakat desa Lok Baintan untuk mengolah ilung menjadi kertas.

\section{SIMPULAN}

Tawaran solusi untuk Porgram Pengembangan Desa Lok Baintan melalui pemberdayaan masyarakat "Desa Sahabat Sampah", yaitu dengan memanfaatkan ilung menjadi kertas berbasis komunikasi partisipatif di nilai efektif. Program pengabdian kepada masyarakat melalui program Pengembangan Desa Mitra diharapkan mengurangi sampah ilung di sungai Martapura khusunya sekitar Desa Lok Baintan. Penggunaan ilung sebagai bahan pokok pembuatan kertas selain dapat mengurangi sampah ilung juga dapat membuka peluang usaha baru yaitu dengan produk kertas yang bisa ditransformasikan menjadi kertas itu sendiri, kartu nama, amplop dan tas kertas. Ini dapat membentuk ruang perekonomian baru bagi masyarakat setempat khusunya di bidang ekonomi kreatif. Kegiatan ini memiliki manfaat langsung untuk masyarakat yang bermukim di bantaran sungai, danau dan rawa yang memiliki banyak ilung. Untuk itu, kegiatan ini disarankan untuk diduplikasi ke desa lain yang memiliki permasalahan yang serupa.

\section{UCAPAN TERIMA KASIH}

Kegiatan pengadian kepada masyarakat ini didanai oleh Direktorat Riset dan Pengabdian kepada Masyarakat, Kementerian Riset, Teknologi, dan Pendidikan Tinggi melalui Program Pengembangan Desa Mitra. Program kepada masyarakat didukung juga oleh beberapa pihak antara lain; LPPM Universitas Islam Kalimantan (Uniska) Muhammad Arsyad Al Banjari, mahasiswa yang terlibat, Bapak Sapriansyah, S.Ag. selaku Kepala Desa, Ibu Herna Rusnawati selaku ketua PKK, dan masyarakat Desa Lok Baintan.

\section{DAFTAR PUSTAKA}

Aronson, D., Bostic, R., Huck, Rownsen, R. (2014). Continuum Relationship and Small Business Use of Market. $J$. Urban econ, (55), 46-67.

Budiman, M. A., Mawardi, M. K., \& Hakim, L. (2017). Identifikasi potensi dan pengembangan produk wisata serta kepuasan wisatawan terhadap produk wisata (Studi kasus di Pantai Bangsring, Kabupaten Banyuwangi). Jurnal Administrasi Bisnis (JAB), 50(4), 55-63

Lim, H. (2008). SMEs Development policy environment and challenges in Singapore. Singapore: Singapore Institute For International Affairs.

Machfoedz, I., \& Suryani, E. (2008). Pendidikan kesehatan bagian dari bagian dari promosi kesehatan. Yogyakarta, Indoneisa: Fitramaya.

Mulyana, D. (2007). Ilmu komunikasi: Suatu pengantar. Bandung, Indonesia: Remaja Rosdakarya.

Priyono, O. S., \& Pranarka, A. M. W. (1996). Pemberdayaan Konsep, Kebijakan dan Implementasi. Jakarta, Indonesia: Center for Strategic and International Studies.

Rahim, S. A., (1994). Participatory development communication as a dialogical process. New Delhi, India: Sage Publication.

Rinawati, R. (2006). Komunikasi dan pembangunan partisipatif. Jurnal MediaTor, 7(2), 175-184.

Servaes, J. (2005). Communication for development: One world, multiple cultures. Cresskill, NJ: Hampton Press.

Taufikurahman, A. (2008). Prospek pemanfaatan eceng gondok dalam industri pulp dan kertas. Berita Selulosa, 29(1), 3-7. 